\title{
VALIDITY AND EFFECTS OF CONTRACTS IN THE CONFLICT OF LAWS
}

\author{
ERNEST G. LORENZEN \\ Professor of Law, Yale University, School of Law
}

There is notopic in the conflict of laws in regard to which there is greater uncertainty than that of contracts. In this country there is no agreement even regarding the fundamental principles that should govern. Elsewhere there is less dispute concerning the general principles, but much difference of view in their application to concrete situations. Under these circumstances a discussion of the question in broad outline may not be amiss. Since an inquiry into the law governing "capacity" to contract and the "formalities" with which a contract must be executed raises a number of special problems, it has been deemed best to omit the discussion of this phase of the subject in the present article, except in so far as it may bear upon the intention theory in general, and to restrict its scope to the intrinsic validity of contracts, and to their effects. The purpose of this article will have been attained if it has pointed out the difficulties in the way of finding a simple solution of the conflicts arising from the diversity of laws relating to contracts (apart from capacity and form), and if it has succeeded in suggesting, in the light of the best juristic thought of the world, some guiding principles by means of which the solution of the particular problems may be found. In this problem, as in most others arising in the conflict of laws, some light may be derived from the juristic discussions of foreign writers and from the experience of foreign nations. So far as it may serve the purpose of this article the foreign law and literature will therefore be considered.

I.

Let us examine in the first place the rules which the courts purport to follow in determining the intrinsic validity and effects of contracts from the standpoint of the conflict of laws.

\section{A. ANGLO-AMERICAN LAW}

(I) American Law. A few years ago Professor Beale undertook the laborious task of examining in detail the English and American cases on this subject. ${ }^{1}$ It appears from his article that our law is in a state of great confusion and that the courts of the same state often

1 (I9Io) 23 HARv. L. REv. 79. 
follow different theories. By way of general summary Professor Beale concluded that at the time of writing six states, one of which was doubtful, had adopted the law of the place of making; that I6 states, of which five were doubtful, had adopted the law of the place of performance; and that II states, besides the District of Columbia, had adopted the law intended by the parties. ${ }^{2}$ The federal courts have generally applied the law of the state or country intended by the parties. Some of them have presumed that the parties intended their contract to be governed by the law of the place of making; others, by that of the place of performance. ${ }^{3}$

(2) English Laze. That the law intended by the parties controls the rights and duties arising out of valid contracts is settled law. Dicta in the decisions adopt this principle also as regards the validity of contracts, and Dicey maintains that the law with reference to which the parties contracted has been fully adopted by the English courts. According to Westlake, ${ }^{5}$

"the law by which to determine the intrinsic validity and effects of a contract will be selected in England on substantial considerations, the preference being given to the country with which the transaction has the most real connection, and not to the law of the place of contract as such."

No case appears to have arisen in England where the nature of the contract and circumstances of the case pointed to a law which would render the contract invalid, and where the intention was expressed to

\footnotetext{
Id., 207.

Id., $100-103$.
}

- Conflict of Laws (2d ed. Ig08) 529, 545, 556. After stating in Exception I that a foreign contract will not be enforced in England if it would be contrary to public policy, Dicey adds the following:

"Exception 2.-A contract (whether lawful by its proper law or not) is invalid if the making thereof is unlawful by the law of the country where it is made (lex loci contractus) (?)" (p. 55I).

"Exception 3.-A contract (whether lawful by its 'proper law or not) is, in general, invalid in so far as ( 1 ) the performance of it is unlawful by the law of thi-country where the contract is to be performed (lcx loci solutionis); or (2) the contract forms part of a transaction which is unlawful by the law of the country where the transaction is to take place. ...

"SUB-RULE 3:-In the absence of countervailing considerations, the following presumptions as to the proper law of a contract have effect:-

"First Presumption.-Prima facie the proper law of the contract is presumed to be the law of the country where the contract is made (lex loci contractus); this presumption applies with special force when the contract is to be performed wholly in the country where it is made, or may be performed anywhere, but it may apply to a contract partly or even wholly to be performed in another country.

"Second Presumption.-When the contract is made in one country, and is to be performed either wholly or partly in another, then the proper law of the contract, especially as to the mode of performance, may be presumed to be the law of the country where the performance is to take place (lex loci solutionis)" (p. 563).

${ }^{3}$ Private International Law (5th ed. I9r2) 305. 
have the contract governed by another law which would support it, but according to Westlake, ${ }^{6}$ it may be confidently expected that the courts will under such circumstances decline to uphold the contract.

\section{B. CONTINENTAL IAW}

(I) French Law. The intention of the parties is said to govern the intrinsic validity and effects of contracts, ${ }^{7}$ subject to the rules of public order. $^{8}$ In the absence of an express stipulation or special circumstances showing a contrary intention, the parties will be deemed to have contracted with reference to the law of the place where the contract was entered into. ${ }^{D}$ Where the parties have the same nationality, the presumption will be that they contracted with reference to their national law. ${ }^{10}$

(2) German Laze. The intention of the parties is controlling, subject to the rules of public policy. Where the intention of the parties is not expressed, and does not appear from the circumstances, the lex loci was formerly applied.11 Through Savigny's influence the

'Ibid. (Feb. 23, I864), (I864) Sirey, Pt. I, 385; (March 9, 189r), (I89r) Dalloz, Pt. I, 459; (Feb: 6, 1900), (I900) Sirey, Pt. I, 16r, and note; (Dec. 5, I9ro), (IVII) 7 REVUE DE DROIT INTERNATIONAL PRIVE, 395 .

Matters relating to reality of consent are often regarded as belonging to "capacity" and as being subject therefore to the personal law. Aubry (1896) 23 Cluner, 472-474; Audinet, Principes élémentaires du droit international privé (2d ed. 1906), 295; Durand, Essai de droit international privé (1884) 419; Despagnet, Précis de droit international privé (5th ed. 1909), 903-904; 8 Laurent, Le droit civil international (188I) 228-229; Pillet, Principes de droit international privé (1903) $45 a$ note $I, 456$. Valery holds that all rules relating to reality of consent are rules of public order, so that a contract will not be enforced if it is contrary to the provisions of the lex fori in this respect. Manuel de droit international privé (1914) 958.

"The term "public order" is used in many different senses. Valery, for example, operates with four varieties. With respect to the defence of illegality he holds that if the contract is valid according to the French local rules, the foreign contract will be enforced: If it is illegal according to the local French law, no effect will be given to it in the following cases: (I) If at least one of the parties is French and the performance of the contract would violate a French law of "personal" public order; (2) if the contract is to be performed in France and such performance violates the French "territorial" public order; (3) if the case falls within the French "personal and territorial" public order, for example, if one of the parties is French, or if the contract is made between foreigners in France; (4) if the conract violates French rules of "absolute" public order. Valery, op. cit., $962-965$.

- See cases in note 7. See also Bard, Précis de droit international pénal et privé (1883) 266; Despagnet, op. cit., 882; Durand, op. cit., 420; 2 Laurent, op. cit., 414-416; Surville et Arthuys, Cours élémentaire de droit international privé (6th ed. 1915) 300; Weiss, Traité de droit international privé (2d ed. 1912) 364.

${ }^{10}$ App. Paris (March 19, 1907), (1907) Nouvelle Revue PRatroue DE DRoIr INTERnational PRIVE, 302; Audinet, op. cit., 283; Surville et Arthuys, op. cit., 299; 4 Weiss, op. cit., 355.

${ }_{11}$ Gierke, Deutsches Privatrecht (1895) 232, note 67. 
courts have abandoned this view in favor of the law of the place of performance. Gebhard's draft of the German Civil Code relating to private international law pronounced itself in favor of the "debtor's" domicil, the doctrine first championed by Bar. The first commission did not accept Gebhard's recommendation, and preferred, in the absence of circumstances pointing to a contrary intention, the application of the lex loci. This rule was retained by the second commission, but the Federal Council struck out all provisions relating to the intrinsic validity and effects of contracts and left the question for determination by the courts. Although the reason for the action of the Federal Council is not clear, it was probably in part due to the fact that it did not regard the science of the conflict of laws, so far as it relates to the above matter, as sufficiently advanced to warrant the-adoption of a final rule. ${ }^{12}$ Since the adoption of the civil code, the courts have continued to follow the law of the place of performance, ${ }^{13}$ except where the nature of the contract or the circumstances of the case convinced the court that the parties contracted with reference to some other law. ${ }^{14}$ Some decisions have been in favor of the law of the debtor's domicil. ${ }^{15}$ In the case of bilateral agreements, where the place of performance of one party is different from the place of performance of the other, the duties of each party are determined with reference to the lex solutionis of his own part of the contract, ${ }^{16}$ unless, in accordance with the presumed intention of the parties, a single law can be deemed applicable to the rights and duties of both contracting parties. ${ }^{17}$ Such a single law has been held to apply also where the existence of the contract itself is in question. ${ }^{18}$

(3) Italian Law. Under the influence of Mancini, Article 9 of the Preliminary Dispositions of the Civil Code was adopted, the third paragraph of which provides as follows:

"The substance and effect of obligations are deemed to be regulated by the law of the place in which the acts were done, and, if the contracting parties are foreigners and belong to the same nationality, by their national law. The showing of a different intent is reserved in each case."

(4) Law of other countries. The rest of the continental countries

\footnotetext{
${ }^{12} \mathrm{Krohn}$, Die Vertragsobligationen in materieller Beziehung nach deutschem internationalen Privatrecht (1909) 16.

${ }^{13}$ Imperial Court (April 23, I903) 54 RG 3I6; (July 4, I904) I5 ZErTSCHRrFT für internationales Privatrecht, 285; (Dec. 5, Igri) 23 id. 346; (Oct. II, I9I0) 24 id. 320; (Oct. 2, I9II) 23 id. 340; (April 19, I910) 73 RG 379; (March II, I919) $95 \mathrm{RG}$ I64.

14 Imperial Court (Sept. 2I, I899) 44 RG 300.

${ }^{15}$ Imperial Court (Oct. I2, I905) 6r RG 343; (Feb. I2, 1906) 62 RG 379.

${ }^{16}$ Imperial Court (Oct. 13, I894) 34 RG I91; (April 28, 1900) 46 RG 193 (April 21, I902) 51 RG 218; (June 16,1903 ) 55 RG ro5.

${ }^{27}$ Imperial Court (April 4, I908) 68 RG 203; (Apr. 19, I9ro) 73 RG 379; (Feb. 4, I9I3) 8I RG 273 .

${ }^{18}$ Imperial Court (Feb. 13, I89r) 47 Seuffert's ARchIv, 3.
} 
appear likewise to have adopted the intention of the parties as the test of the law determining the essential validity and effects of contracts; subject to their respective rules of public policy. Where the intention is not expressed, Belgium, ${ }^{20}$ Holland, ${ }^{21}$ Portugal. ${ }^{22}$ Russia, ${ }^{23}$ and Spain $^{24}$ presume that the parties contracted with reference to the law of the place of contracting. Greece ${ }^{25}$ and Hungary ${ }^{26}$ prefer in such a case the law of the place of contracting, and Sweden, ${ }^{2 \tau}$ that of the domicil of the debtor. In Norway the law of the place of contracting governed formerly, ${ }^{28}$ but there appears to be a strong tendency in favor of the law of the debtor's domicil. ${ }^{28}$ The Swiss courts appear to apply, unless an intention to the contrary is shown, the law of the place of contracting if the contract is made in Switzerland. ${ }^{30}$ Swiss law has been applied also where a contract made abroad was to be performed in Switzerland ${ }^{30 a}$ or where Swiss subjects entered into a contract while on a visit abroad. ${ }^{31}$ Austria presumes with respect to contracts made between foreigners in Austria that they contracted with reference to the local law. ${ }^{82}$ The same presumption exists where a foreigner enters into a contract with another foreigner or with an Austrian abroad. ${ }^{38}$ Where a foreigner enters into a contract in Austria whereby he confers only benefits upon the other contracting party, Austrian law or his national law will control, according as the one law or the other favors most the validity of the transaction. ${ }^{84}$ This rule holds, true whether the other contracting party is an Austrian or a foreigner. The application of Austrian law is mandatory, so as to exclude the intention of the

${ }^{\circ}$ Trib. Civ. de Charleroi (June 3, Ig0I) 30 Civner, 898; Trib. de Commerce de Bruxelles (Jan. 2, I902), (I903) jo ClunET, 409; App. Brussels (June 29 , rg07), (Ig08) 35 Clunet, 562

${ }^{2}$ Court of Appeals of Arnheim (Jan. 19, I898), (I900) 27 ClUNEr, 840; Court of Appeals of Bois-de-Duc (Jan. 22, Igor), (rgo4) 3 I Cluner, 457.

- Commercial Code, sec. 4.

${ }^{27}$ I Klibanski, Handbuch des gesamten russichen Zivilrechts (IgIr) 445;

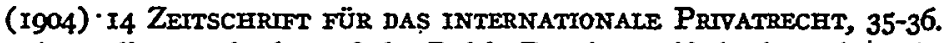

According to the law of the Baltic Provinces, if the intention of the parties is not expressed, the law of the place of performance governs. (I877) 4 CLUNEr, 208.

24 Torres Campos, Elementos de derecho internacional privado (4th ed. 1913) 274 and cases cited.

${ }^{25}$ Art. 6 of Law of Oct. 29 (Nov. 10) 1856; Areopage, Section B (1899 no. 25), (I903) 30 CIUNET, 210.

${ }^{20}$ Royal Court (rgi4) 4I CiUner, roog.

"Synnestvedt, Le droit international privé de la Scandinavie (I904) 259.

Id., $26 \mathrm{r}$.

Ibid.

${ }^{\circ}$ Federal Tribunal (Jan. 22, 1904), (I905) 32 CluNET, 453.

$\mathrm{x}_{2}$ Federal Tribunal (June 21, I907), (1908) 35 Cluner, 932.

"Civil Court of Geneva (March I7, Ig04), (Ig07) 34 CLuner, 208.

" Civil Code, sec. 36.

Id., sec. 37 .

st., sec. 35 . 
parties in the case of contracts entered into in Austria between Austrians, or between an Austrian and a foreigner, except where a foreigner bestows an exclusive benefit upon an Austrian without imposing any duty. ${ }^{35}$

\section{LATIN-AMERICAN LAW}

(I) Convention of Montevideo. So far as the provisions of the Convention of Montevidio, of I889, are applicable, the South American states are bound by the following general rules, as regards civil transactions :

"Article 33. The same law [law of the place of performance] governs as regards their (a) creation; (b) nature; (c) validity; (d) effects; (e) consequences; (f) performance ; in fact, all matters concerning contracts whatever their nature.

"Article 34. Contracts regarding specific things are governed therefore by the law of the place where they are at the time of the making of the contract. Those relating to unascertained goods sold by description, by the law of the debtor's domicil at the time of the execution of the contract; those relating to fungible things, by the law of the debtor's domicil at the time of the making of the contract. Those relating to the rendering of services (a) with respect to things, by the law of the place where such things are at the time the contract was made; (b) if their efficacy is connected with some special place, by the law of the place where the effect is to be produced; (c) in other cases, by the law of the debtor's domicil at the time of the making of the contract.

"Article 35. A contract to exchange things situated in different places which are subject to different laws is governed, if the parties have a common domicil, by the law of their domicil at the time the exchange was made, and in the absence of a common domicil, by the law of the place where the exchange was made.

"Article 36 . Accessory contracts are governed by the law applicable to the principal obligation.

"Article 37. The perfection of contracts made by correspondence or agents is determined by the law of the place from which the offer was sent."

Special rules are laid down also in the Convention on Commercial Law with respect to bills of exchange and other special contracts. Respecting bills of exchange, it is provided that the legal relations resulting from the drawing are to be governed, as between the drawer and the payee, by the law of the place of issue, and as between the drawer-and the drawee, by the law of the drawee's domicil. The obligation of the acceptor in respect to the holder and the defences available to him are determined by the law of the state where the acceptance took place. ${ }^{36}$

(2) Argentine Lare. The law of the place of performance controls

\footnotetext{
${ }^{23}$ Stubenrauch, Commentar zum österreichischen allgemeinen bürgerlichen Gesetzbuche (6th ed. 1892 ) 98.

${ }^{3}$ Secs. 27-28.
} 
the nature, obligation, and validity of contracts in general. ${ }^{37}$ The essential requisites of bills and notes are determined by the law of the place where the instrument was executed. ${ }^{38}$

(3) Brazilian law. The new Brazilian Civil Code contains the following general provisions : ${ }^{39}$

Intr. Art. 13. "With respect to the substance and effect of obliga $\lrcorner$ tions, the law of the place where they were entered into shall govern, unless otherwise stipulated. ${ }^{.0}$

"Single Paragraph. However, the Brazilian law shall always govern:

"I. Contracts entered into in foreign countries which are to be performed in Brazil .

"II. Obligations contracted in a foreign country between Brazilians."

(4) Chilean Law. The Civil Code provides that the effect of contracts to be performed in Chile is to be controlled by Chilean law.:1 According to the Chilean writers the law of the place where the contract is made governs otherwise. ${ }^{22}$ The Supreme Court of Chile has stated in a recent decision that a contract is deemed to produce its effect in Chile if it is necessary to ste the defendant in the Chilean courts, notwithstanding the fact that the agreement called for performance in another state. ${ }^{13}$

(5) Mexican law. The Civil Code of the Federal District and of the District of Lower California provides:

Art. I6. The obligations and rights arising from contracts and wills executed in a foreign country by Mexicans of the Federal District or Lower California are governed by the provisions of this code, if they are to be performed in the Federal District or in Lower California.

Art. 17. If the contracts and wills to which the preceding paragraph refers are executed by a foreigner and are to be performed in the Federal District or in Lower California, the person executing the same shall be free to choose the law that shall determine their substantive validity so far as they relate to movable property. As regards immovable property, the provisions of Art. I3 shall control.44

\footnotetext{
${ }^{3}$ Civil Code, Arts. I239, 1244, 1243, 1248; Molina, El derecho internacional privado y el codigo civil Argentino (1882) I83; 3 Alcorta, Curso de derecho internacional privado (i 892$) 233$.

${ }^{*}$ Commercial Code, Art. 738 .

Bills of exchange are governed by the law of the place of execution. Art. 47, Bills of Exchange Law.

${ }^{\text {to }}$ Trib. Sup. de Rio Grande do Sul (March 15, 1910), (19Ir) 38 ClunEr, 1313;

Octavio, The Conflict of Lazes of Brazil (1919) 28 Yare LAw JouRinar, 467.

"Art. 16, Civil Code.

- Fabrès, Le droit international privé dans la législation de Chile (I887) I4

Cluner, 140; I Salas, Elementos de derecho civil (I912) 45.

(June 8, I9II), (I9I3) 40 Cluner, r33r.

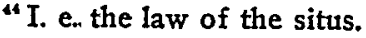




\section{JAPANESE LAW}

Art. 7 of the Law Concerning the Application of Laws in General provides as follows:

"The law governing the creation and effect of a legal transaction is deternined by the will of the parties.

"If the will of the parties is not clear the law of the place where the transaction was entered into shall control."

As regards contracts by correspondence, the Japanese law enacts as follows : ${ }^{45}$

"In the case of a unilateral act, the place from which the notice is despatched is regarded as the place of the act; while in the case of a bilateral act [contract] the place from which the offer was despatched is regarded as the place of the act and the formation and effect of the act are governed by the law of that place. If, however, the recipient of the offer was ignorant, at the time of his acceptance, of the place from which the offer had been despatched, the place of the offeror's domicil is regarded as the place of the act."

The above summary of the law of the different countries shows that they are practically agreed upon the adoption of the intention of the parties as the fundamental rule governing the validity and effects of contracts (apart from capacity and formalities) in the conflict of laws. There is a vast difference of view, however, in the interpretation of this principle with respect to the various classes of contracts and the multitude of questions arising from contracts in general. Much obscurity exists also regarding the application of the principle itself to matters affecting the validity of contracts as distinguished from their effects. To the extent that the English courts and the decisions of the Supreme Court of the United States and of the state courts have adopted this rule, it is apparent, therefore, that they have not committed themselves to a doctrine which has no support elsewhere, but that they accepted, on the contrary, a view commanding practically universal assent. We shall have to inquire, therefore, (I) into the meaning of the doctrine that the intention of the parties governs; (2) into the consistency of this doctrine with the fundamental conceptions of Anglo-American law; (3) into the application of this doctrine to the validity and effects of contracts.

ORIGIN AND DEVELOPMENT OF DOCTRINE ON THE CONTINENT THAT THE INTENTION OF THE PARTIES IS THE GOVERNING LAW

The origin of the doctrine that the intention of the parties governs the validity and effects of contracts, known as the "autonomy doctrine,"

\footnotetext{
-Art. 9, Law Concerning the Application of Laws in General; de Becker, International Private Law of Japan (Igrg) 98.
} 
is to be found in the writings of Dumoulin. Before his time the views expressed by Bartolus had been generally followed. A distinction was made between the natural consequences of a contract, i. e, those inhering in the contract itself, which Bartolus made subject to. the law of the place where the contract was made; and the consequences arising subsequent to its formation as the result of negligence or delay, which he determined according to the law of the place which had been agreed upon for performance. If no place of performance was specified, Bartolus would apply the law of the forum as the law of the place where the negligence or delay was deemed to have occurred. ${ }^{48}$ In support of the above distinction Bartolus relied upon certain passages in the Corpus Juris Civilis. Paul de Castro, ${ }^{47}$ a follower of Baldus, based the application of the lex loci upon the fiction that it is the place where the contract was born, contracts like persons, being subject, according to this writer, to the law of the place of their origin; and Rochus Curtius ${ }^{88}$ justified it on the ground that the parties had tacitly submitted to the law of the place of contracting. Whatever the theory of the old statutists may have been in this matter, it is clear that in their opinion the lex loci governed the intrinsic validity and direct effects of contracts as a matter of law, regardless of the intention of the parties.

Dumoulin proclaimed with respect to contracts the principle that the will of the parties is sovereign, and that, if the will is not expressed, it must be sought in the surrounding circumstances, the place of contract being one, but only one, of these circumstances. ${ }^{40}$ The application of the law of another state in the matter of contracts is, in the eyes of Dumoulin, not so much the application of a law, as the enforcement of a tacit agreement assumed and sanctioned by such law, to which he attributes the same force as is possessed by an express agreement. This new doctrine was attacked by d'Argentré, the champion of the theory of the territoriality of laws, whose influence prevailed in France until the time of Bouhier and Pothier. The lex loci was considered therefore as having obligatory force, but the rule was subject to many exceptions. Of the later French statutists Boullenois defended most whole-heartedly Dumoulin's doctrine, which became the prevailing view in Pothier's time. Early in the nineteenth century a strong' opposition manifested itself again in France to the theory that the application of the lex loci results from the will of the parties, but the autonomy doctrine became firmly established through a decision of the Court of Cassation in 1836 . Since then it has been applied not only to the determination of the rights and duties arising out of contracts admitted to be valid, but also with respect to the intrinsic validity of contracts in general. In connection with this new development Savigny's influence

* Bartolus, Conflict of Lazers (Beale's transl. I9I4) I8-20.

"I Lainé, Introduction au droit international privé (1888) I89.

- Id., 205.

Id., 2209 . 
appears to have been especially felt. ${ }^{50}$ The views of this writer that the law of the place of performance should control, in the absence of an expressed declaration to the contrary, were not accepted, however, the law of the place of contracting and the common national law being preferred instead.

Dumoulin's view that the will of the parties, expressed or implied, is the leading factor in the determination of the law governing contracts was accepted also by the Dutch writers. Huber says :

"The place, however, where a contract is entered into, is not to be considered absolutely; for if the parties had in mind the law of another place at the time of contracting the latter will control. "Everyone is (Digest $44,7,2 I$ )."

The great Dutch writer John Voet ${ }^{52}$ expressedly recognized the will of the parties to be sovereign in the field of contracts, except as regards capacity, formalities, and matters of public policy, but as he did not emphasize this part of his doctrine, it was lost sight of in his huge commentary on the Pandects and exercised comparatively little influence upon the law of foreign countries.

The general acceptance on the continent today of the doctrine that the intention of the parties is the controlling consideration in the conflict of laws, so far as as it concerns contracts, is due in large measure to the influence of Savigny. In accordance with his underlying theory of the Conflict of Laws, he seeks to discover for every legal relation that territory to which, in its proper nature, it belongs or is subject (in which it has its seat). Savigny contends that the forum of the obligation coincides with its true seat, both depending upon the voluntary submission of the parties to the local law. Such submission is generally by a tacit declaration of will and is always excluded by an express declaration to the contrary. "We have therefore to inquire," he says, "to what place the expectation of the parties was directed--what place they had in their minds as the seat of the obligation. At this place we must fix the forum of the obligation, in virtue of their voluntary submission. But as the obligation itself, as a legal relation, is incorporeal and has no locality, we must seek, in its natural process of development, obligation, in order to give it; as it were, a body"

The expectation of the parties being in the estimation of Savigny directed to fulfilment, he concludes that they must have intended to submit to the law of that jurisdiction: ${ }^{54}$ The place of performance

\footnotetext{
so i Donnedieu de Vabres, L'évolution de la jurisprudence française en matière
des conflits des lois ( 1888 ) I80-18I.

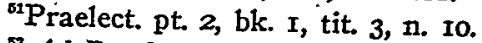

Ad Pandectas, pt. 2, bk I, tit. 4, n. 18.

${ }^{53}$ Private International Laze (Guthrie's transl. 1880) 198.

IId., 209-210.
} 
is, in the first place, the place which is specially fixed as the place of performance. Such place may result from an express agreement or from the fact that the performance can be effected only in a particular place. If no place of performance has been fixed in the manner specified, the plate of performance is (a) the debtor's place of business, if the duty in question arose out of a transaction connected with such business; (b) the place where the contract was entered into, if the circumstances created an expectation that its performance was to be at the same place; (c) the debtor's domicil, if the duty was assumed in that state. or if none of the other conditions above mentioned exist. ${ }^{55}$

"All these cases,," says Savigny,,"

"however various they appear, and however accidental their connection may seem, yet admit of being reduced to a common principle. It is always the place of fulfilment that determines the jurisdiction, either that expressly fixed, or that which depends on a tacit expectation. In both cases a voluntary submission to this jurisdiction is to be assumed, unless an express declaration to the contrary excludes it. .

"The derivation of the rules here laid down from the presumed voluntary submission of the debtor to a particular territorial law, has some weighty practical results which must here be reviewed.

"A. This territorial law ceases to be applicable when it is at variance with an absolute, strictly positive rule of law in force at the place of the courc which decides the question (sec. 349); for in such cases the free-will of the parties can have no influence at all.

"B. The territorial law likewise ceases to apply when the presumption of voluntary submission is excluded by an expressed contrary intention." 57

An extreme expression of the intention theory is advocated by the great Belgian jurist Laurent; who says : ${ }^{58}$

"Whenever parties contract they are legislators; their will takes the place of law. It follows from this that in the matter of contracts the question is governed by entirely different principles from those applied to other juristic acts. In reality it is no longer a question of statute, but solely of the will of the parties. ... Thus it is that in the matter of status the will of the parties counts for nothing; it is the law that controls, either the personal or the territorial law. In the matter of contracts, on the other hand, the will of the parties is everything. They themselves made the law; it is therefore their will which determines by what law they are to be governed.

"The German jurists have given to this doctrine that the will of the contracting parties determines the law that shall govern their agreement a significant name-they call it autonomy, to indicate that the individuals are in this matter autonomous, that is to say sovereign, as were formerly the autonomous cities. The expression is exact, provided one limits the autonomy of the individuals to private rights and inter-

${ }^{35} I d ., 209-210,2222$.

${ }^{\infty} I d ., 210$.

"Id., 223.

2 Laurent, op. cit. note 7, at pp. $383-384$ 
ests. It is certain that the contracting parties cannot determine their status and capacity; these matters belong to public order, and as such fall within the exclusive province of the legislator. Still less can they regulate what belongs to the sovereign power. To express myself in the language ordinarily used, everything belonging to status and to the real statute is beyond the autonomy of the individuals."

Against these exorbitant claims in support of the autonomy doctrine, put forward by Laurent, a reaction has set in on the Continent, where it is conceded to-day that the will of the parties does not stand above the law, but that it can operate only within the limits prescribed by law."

\section{ORIGIN AND DEVELOPMENT OF INTENTION THEORY IN ENGLAND AND} THE UNITED STATES

The doctrine that the intention of the parties governs in the matter of contracts from the standpoint of the conflict of laws was introduced into Anglo-American law by a dictum of Lord Mansfield in the case of Robinson $v$. Bland. ${ }^{\text {Bo }}$ This was an action of assumpsit in three counts. The first count was on a bill of exchange drawn at Paris by the intestate on himself in England for $£ 672$, and accepted by the intestate. The second was for $£ 700$ lent in France to the intestate. The third count was for $£ 700$ had and received in France by the intestate to the use of the plaintiff. It was found that the bill of exchange was given at Paris for $£_{300}$ there lent by the plaintiff to the intestate, and lost by the latter to the plaintiff at play, and for $£_{372}$ more, which the intestate had lost in the same way. It was found that the money lost at play between gentlemen could be recovered in France as a debt of honor before the marshals of France, though such money was not recoverable in the ordinary courts, and that money lent to play with could be recovered in France as a debt in the ordinary courts, and that both plaintiff and intestate were gentlemen. The Court of King's Bench decided that the bill of exchange was void and that the money lost at play could not be recovered, but that the money lent could be recovered. Two of the three judges, including Lord Mansfield, found that the law of France and the law of England were identical with respect to the above points. Lord Mansfield stated, however, that he would have reached the same conclusion had the law of France and of England been proved to be different. In support of the application of English law he gave two reasons:

"First, the parties had a view to the laws of England. The law of the place can never be the rule, where the transaction is entered into with an express view to the law of another country, as the rule by which it is to be governed. Huberi Praelectiones, lib. I, tit. 3 pa. 34, is clear and distinct: 'Veruntamen, etc. locus in quo contractus, etc. potius considerand', etc. se obligavit.' Voet speaks to the same effect.

Pillet, op. cit. note 7, at pp. $443 \mathrm{ff}$.

( 1760, K. B.) 2 Burr. I077. 
"Second reason-... In every disposition or contract where the subject matter relates locally to England, the law of England must govern, and must have been intended to govern. Thus, a conveyance or will of land, a mortgage, a contract concerning stocks must be all sued upon in England; and the local nature of the thing requires them to be carried into execution according to the law here."

Lord Mansfield's dictum has been adopted and developed by subsequent English cases.

In the case of In Re Missouri S. S. Co. Lord Justice Fry summed up the present doctrine of the English courts as follows: :2 $^{2}$

"I think, therefore, the general principle on which we have to proceed is one which admits of no doubt; and the inquiry, therefore, is this: Looking at the subject-matter of this contract, the place where it was made, the contracting parties, and the things to be done, what ought to be presumed to have been the intention of the contracting parties with regard to the law which was to govern this contract? By that I mean to determine its validity and its interpretation."

Dicey ${ }^{83}$ concludes from the English decisions that the intention of the parties governs the effects of contracts. As regards intrinsic validity Dicey contends, however, that the parties can subject their contract to the operation of foreign law only indirectly, their intention being of great weight in determining, where the facts connect a contract with several states, whether the contract is a contract of the one state or of the other. Westlake ${ }^{64}$ feels that the English courts have come to determine the intrinsic validity of contracts on substantial considerations without reference to the intention of the parties, namely, by the law of the state with which the contract has the most real connection.

Before the above decisions were rendered Lord Mansfield's view had been adopted in the United States. ${ }^{65}$

Story, who purports to follow Lord Mansfield's dictum, expresses himself as follows:

"The ground of this doctrine, as commonly stated, is that every person contracting in a country is understood to submit himself to the law of the place, and silently to assent to its action upon his contract. . . . It would perhaps be more correct to say that the law of the place of the contract acts upon it, independently of any volition of the parties, in virtue of the general sovereignty possessed by every nation to regulate all persons and property and transactions within its own territory."

"Id., 210.

${ }^{c 2}$ (1889) L. R. 42 Ch. Div. 32I, 340-341.

Op. cit., 545-547, 814 ff.

os Op. cit., 305.

${ }^{85}$ Ludlow v. Van Rensselaer (1806, N. Y. Sup. Ct.) I Johns. 94; Powers v. Lynch (I807) 3 Mass. 77; Thompson v. Ketcham (I8II N. Y. Sup. Ct.) 8 Johns. I46; Fanning v. Consequa (1820 N. Y. Sup. Ct.) I7 Johns. 5II ; Prentiss $v$. Savage (I8r6) I3 Mass. 20; Van Reimsdyk v. Kane (I812, U. S. C. C. D. R. I.)

I Gall. 37x; Cox v. United States (1832, U. S.) 6 Pet. 172.

${ }^{\circ}$ Conflict of Laws (8th ed. I883) 348-349. 
"Another rule illustrative of the same general principle is, that the law of the place of the contract is to govern as to the nature, the obligation, and the interpretation of the contract, locus contractus regit actum."Br

"The rules already considered suppose that the performance of the contract is to be in the place where it is made, either expressly or by tacit implication. But where the contract is, either expressly or tacitly, to be performed in any other place, there the general rule is in conformity to the presumed intention of the parties that the contract, as to its validity, nature, obligation, and interpretation, is to be governed by the law of the place of performance. This would seem to be a result of natural justice." 88

Story does not define what he means by the "presumed intention" of the parties, and the same vagueness is found in practically all subsequent cases. Most of them apply the law of the place of performance when it differs from that of the place of contracting, without reference to the other surrounding circumstances. In certain cases, especially in cases involving the defence of usury, the presumption that the parties contracted with respect to the law of the place of performance is deemed to be rebutted if the contract is void under that law but valid under the law of the place of contracting. There are only a few cases which seek to find the law with respect to which they feel that the parties would have contracted, had their attention been called to the matter, from an actual examination of the attendant circumstances. One of these is Grand $v$. Livingston. ${ }^{60}$ The question before the court in that case involved the validity of a stipulation against negligence in a bill of lading which had been issued in Massachusetts for the transportation of horses to New York. " The determination of this question," said the learned court, "involves not only a careful examination of the "instrument itself, but likewise of all the circumstances attending its "execution." Regarding the question of intention it made the following observations:

"As was suggested upon the argument, the question of intent can hardly be said to involve the actual mental operations of the parties. For, as a matter of fact, they probably did not stop to consider what was the legal effect of their agreement, or whether there was any diversity in the law of the two states; and, therefore, when we speak of the 'ques'tion of intent,' we are making use of what may perhaps be termed a 'legal fiction'; but, nevertheless, the law does look at the acts of the parties, and the circumstances surrounding them, which may possibly their intention is in harmony with such acts and circumstances."

The position of the Supreme Court of the United States with reference to the law governing the intrinsic validity and effects of contracts

${ }^{67}$ Id., 351.

${ }^{\infty} I d ., 376$.

${ }^{\infty}$ (I896) 4 App. Div. 589, 38 N. Y. Supp. 490. 
is not well defined. ${ }^{70}$ Some of its decisions purport to apply the intention theory, as, for example, the case of Pritchard $v$. Norton. ${ }^{71}$ A bond had been executed by the defendants in the state of New York, in which they undertook to indemnify the plaintiff against all loss arising from his liability as surety on an appeal bond executed by him on behalf of the appellant in a certain suit then. pending in the Louisiana courts. In a suit upon the bond the defence was that the contract was void under the law of New York, the place of contracting, for want of consideration. The Supreme Court, speaking through Mr. Justice Matthews, said : ${ }^{72}$

"The phrase lex loci contractus is used, in a double sense, to mean, sometimes, the law of the place where a contract is entered into; sometimes, that of the place of its performance. And when it is employed to describe the law of the seat of the obligation, it is, on that account, confusing. The law we are in search of, which is to decide upon the nature, interpretation, and validity of the engagement in question, is that which the parties have, either expressly or presumptively, incorporated into their contract as constituting its obligation. It has never been better described than it was incidentally by Mr. Chief Justice Marshall in Wayman v. Southard, Io Wheat. 48, where he defined it as a principle of universal law-the principle that in every forum a 'contract is governed by the law with a view to which it was made."

No effect will be given to the intention of the parties if it is against public policy or if the provisions of a statute of the place of making would be avoided thereby. ${ }^{73}$

As regards the intrinsic validity of contracts continental courts and writers usually content themselves with saying that the intention of the parties governs, subject to the rules of public policy. But when it comes to the solution of particular cases the greatest divergence of opinion manifests itself. There is no agreement whatever concerning the fundamental basis upon which the rules of the conflict of laws are conceived to rest, nor in regard to the meaning of the term "public "policy." This appeared clearly at the meeting of the Institute of International Law of Paris, in I9I0, when this subject was under liscussion. $^{74}$ The best that could be accomplished at the meeting was the adoption of the following motion, made by Renault: ${ }^{75}$

"In order to avoid the uncertainty arising from the arbitrary action of judges compromising the interests of the parties, the Institute expresses the wish that each country determine as definitely as possible those provisions of law which it will never surrender in favor of another system, even though the latter should be regarded on principle as the competent law to regulate the legal relationship in question."

\footnotetext{
70 See (Igra) 23 HARv. L. REv. 100-I03.

${ }^{72}$ (I882) I06 U. S. I24, I Sup. Ct. I02.

72106 U. S. 136-137.

"See Equitable Life Ins. Co. v. Clements (I8gr) I40 U. S. 226, ir Sup. Ct. 822.

"6 (19I0) 23 ANNUAIRE DE L' INSTITUT DE DROIT INTERNATTONAL, 458-48r.

${ }^{78} \mathrm{Id.}, 478$.
} 
"It is especially desirable that each convention relating to private international law should enumerate the points in regard to which the application of the principles adopted by the convention may be set aside in each contracting state by considerations of public policy."

Since the days of the statutists such operative facts as constitute "capacity" or "formalities" have been set apart on the Continent from the other operative facts relating to the validity of legal transactions and have been placed under special rules, the former being subject to the personal law (lex patriae, lex domicilii) ${ }^{\text {t6 }}$ and the latter to the lex loci (locus regit actum). ${ }^{77}$ The autonomy doctrine has not been extended to these questions. In England and in this country the above matters have not been clearly distinguished from the other elements affecting the validity of contracts. "Capacity" to contract is governed in this country by the law of the state in which the contract is made, without reference to the law of the place of payment, or to the law with reference to which the parties may have otherwise contracted. ${ }^{78}$ In England the law is uncertain on the point. ${ }^{79}$ The lex loci applies also, regardless of the law of the place of performance or the "intention" of the parties, in the matter of formalities, so far as the question is not connected with the statute of frauds, and as such subject to the law of the forum. ${ }^{80}$ These rules are applied even in jurisdictions which adopt the law of the place of performance or the so-called intention theory in the determination of the validity of contracts in other respects. There are a few American cases, however, which have accepted the intention theory even as-regards "capacity"81 and "formalities."82

It will be necessary now to inquire more closely into the meaning of the intention theory, in order to ascertain whether it can be profitably invoked in the solution of the problems arising in the Conflict of Laws with respect to contracts.

(To be continued)

${ }^{36}$ Lorenzen, The Conflict of Laws Relating to Bills and Notes (1919) 65-67.

"Lorenzen, Validity of Wills, Deeds and Contracts as Regards Form in the Conflict of Laws (IgII) 20 YaLE LAW JourNaI; 427, 43 If.

${ }^{78}$ Minor, Conflict of Lawes (I901) I45-146, 416.

${ }^{72}$ Dicey, op. cit., 538 .

${ }^{80}$ Minor, op. cit., 83.

1 Poole v. Perkins (I919) I26 Va. 33I, Ior S. E. 240; Mayer v. Roche (rgog) 77 N. J. L. 681, 75 Atl. 235.

The opinion in Poole $v$. Perkins is based upon a perfectly logical application of the intention theory. If the intention of the parties can govern the intrinsic validity of contracts, there is no logical reason why it should not determine also the "capacity" of the parties to enter into the contract. The reasoning proceeds, however, from the erroneous premise that the application of the lex loci in determining the capacity of the parties when they are present in the state of contracting, results from their intention to contract with reference to such law. See Story, op. cit., 348-349.

${ }^{8}$ Hall v. Cordell (189r) I42 U. S. 116, 12 Sup. Ct. 154 